\title{
Tingkat Pemahaman Masyarakat Lokal sebagai Pemangku Kepentingan Kunci di Tebing Breksi Yogyakarta Terhadap Prinsip-Prinsip Pariwisata Berkelanjutan Berdasarkan Sustdi
}

\author{
Tania Nugraheni Ayuningtyas \\ Program Studi Pariwisata, Fakultas Ilmu Budaya, Universitas Gadjah Mada \\ Email: tania.nugraheni.a@mail.ugm.ac.id
}

\begin{abstract}
Tourism has involved the local communities as a key stakeholders in many tourism destination in Indonesia that are growing due to the phenomenon of digital tourism. In Tebing Breksi Yogyakarta, the growth of tourism sector as a result of the digital tourism phenomenon has made the local people relying on tourism as the main sector to fulfil economic needs after the mining ban from the local government. This research conduct the SUSTDI (Stakeholder Understanding of Sustainable Tourism Development Index) method as a tool to asses level of understanding of local communities about sustainable tourism concepts. According to Timur \& Getz (2009: 223) about the theory of key stakeholder role, three groups of local community has identified such as: host community group, local authority group and tourism industry group. The proportional sampling and stratified random sampling conducted to determined the amount of representative respondent. The result showed that the local communities as the key stakeholder in Tebing Breksi have a high overall level of understanding about the sustainable tourism concept at the scale 4,19 out of 5,00. Despite of that, the level of understanding on the three of the group respondent on question number 23 implies that the "economic development funds should to be used to promote tourism" as "Medium". Moreover, tourism planner can use this results to develop a precise education and training program to improve their knowledge about sustainable tourism development.
\end{abstract}

Keyword: Key Stakeholder, Sustainable Tourism Principles, Tebing Breksi Yogyakarta

\section{Pendahuluan}

Masyarakat lokal sebagai pemangku kepentingan kunci, seringkali terlibat aktif dalam menentukan perencanaan dan manajemen pariwisata di suatu destinasi wisata (Mason, 2003: 87). Masyarakat lokal menjadi salah satu pemain kunci karena menyediakan sebagian besar atraksi wisata sekaligus menentukan kualitas produk wisata (Damanik \& Weber, 2006: 23). Bahkan di beberapa kasus, tidak jarang masyarakat lokal sudah lebih dahulu terlibat dalam pengelolaan pariwisata sebelum adanya kegiatan pengembangan dan perencanaaan (Damanik \& Weber, 2006: 23).
Di Indonesia, keterlibatan masyarakat lokal sebagai pemangku kepentingan kunci dalam pengelolaan pariwisata sebelum adanya kegiatan pengembangan dan perencanaaan banyak terjadi pada destinasi wisata baru yang tumbuh karena fenomena wisata digital. Wisata digital, adalah wisata yang menawarkan dan memenuhi kebutuhan digital, artinya wisatawan pergi ke suatu destinasi untuk kemudian berfoto dan diunggah ke media sosial Instagram dalam rangka menunjukkan eksistensinya. ${ }^{1}$ Namun, keberadaan sektor pariwisata sebagai suatu akibat dari fenomena 
wisata digital yang terjadi secara tiba-tiba pada destinasi wisata digital, membuat masyarakat lokal cenderung impulsif terhadap tren yang sedang berkembang di media sosial hanya untuk meningkatkan keuntungan ekonomi semata ${ }^{2}$ seperti yang terjadi pada area bekas pertambangan yang menjadi Kawasan Objek Wisata Taman Tebing Breksi yang terletak di Desa Sambirejo, Kecamatan Prambanan, Kabupaten Sleman, Daerah Istimewa Yogyakarta (DIY).

Tebing Breksi adalah destinasi wisata baru di Yogyakarta yang diresmikan pada 30 Mei 2015 oleh Gubernur Daerah Istimewa Yogyakarta yaitu Sri Sultan Hamangkubuwono X sebagai "Destinasi Wisata Minat Khusus dan Bumi Perkemahan" yang juga berhasil meraih sebuah penghargaan dari Kementerian Pariwisata Republik Indonesia sebagai Destinasi Wisata Terpopuler di Indonesia berdasarkan sistem voting nasional di media sosial di tahun 2017. Aktivitas pariwisata di Tebing Breksi bermula dari orang-orang yang singgah untuk berfoto pada areal bekas pertambangan ini. Ketika hasil foto itu diunggah ke media sosial terutama Instagram, banyak netizen ${ }^{3}$ yang tertarik untuk datang secara langsung sehingga kepopuleran Tebing Breksi menjadi viral ${ }^{4}$ di tahun 2014. Selanjutnya pada tahun 2015, Pemerintah Provinsi Daerah Istimewa Yogyakarta (DIY) melalui Dinas Pariwisata Provinsi DIY melakukan pembangunan fisik di Tebing Breksi. Setelah itu, terbitlah larangan yang berkaitan dengan penghentian aktivitas penambangan yang dikeluarkan oleh Pemerintah Desa Sambirejo melalui Peraturan Desa Sambirejo Nomor 1 Tahun 2016 tentang Larangan Penambangan Galian C di Zona Merah Kawasan Geoheritage di Wilayah Desa Sambirejo. Sejak saat itu, terjadi transformasi pekerjaan pada masyarakat lokal di Tebing Breksi yang awalnya beprofesi sebagai penambang kemudian dialihkan ke sektor pariwisata. Pariwisata akhirnya menjadi sektor utama pemenuh kebutuhan ekonomi bagi masyarakat lokal yang dahulu berprofesi sebagai penambang. ${ }^{5}$

Menurut Cárdenas, Byrd \& Duffy (2015: 263) apabila masyarakat di sekitar destinasi wisata mengandalkan pariwisata sebagai sektor pemenuh kebutuhan ekonomi, maka itu tandanya sumber daya alam dan lingkungan sekitar menjadi semakin rentan terhadap eksploitasi berlebihan, sehingga edukasi terhadap pariwisata berkelanjutan penting untuk dilakukan dalam rangka menanggulangi dampak yang akan dihasilkan. Oleh karena itu, mengujikan SUSTDI (Stakeholder Understanding of Sustainable Tourism Development Index) untuk mengidentifikasi bagaimana tingkat pemahaman masyarakat lokal sebagai pemangku kepentingan kunci di Tebing Breksi Yogyakarta terhadap prinsip-prinsip pariwisata berkelanjutan menjadi penting karena masyarakat lokal di Tebing Breksi Yogyakarta mengandalkan pariwisata sebagai sektor utama pemenuh kebutuhan ekonomi setelah adanya larangan penambangan oleh pemerintah desa setempat. SUSTDI adalah sebuah studi eksploratif dari penelitian Cárdenas, Byrd \& Duffy (2015), yang menghasilkan alat penilaian secara kuantitatif yang dapat membantu perencana dalam mengukur pengetahuan dan persetujuan masyarakat terhadap prinsip-prinsip pariwisata berkelanjutan. Melalui instrumen SUSTDI, masyarakat lokal juga akan memperoleh edukasi tentang prinsip-prinsip pariwisata berkelanjutan sehingga diharapkan tidak impulsif terhadap tren yang diinginkan oleh wisatawan digital dan lebih berorientasi untuk mewujudkan pariwisata berkelanjutan. Selain itu, Tebing Breksi juga merupakan kawasan geoheritage ${ }^{6}$ yang perlu dilindungi (Surat Keputusan Badan Geologi Nomor 1157.K/73/BGL/2014 tentang Penentuan Kawasan Cagar Alam Geologi Daerah Istimewa Yogyakarta) sehingga memerlukan pembangunan pariwisata yang berkelanjutan.

\section{Kerangka Teori}

Menurut Timur \& Getz (2009: 223) terdapat tiga kelompok peran pada pemangku kepentingan kunci. Pertama, sebagai host community (komunitas lokal) yang meliputi penduduk, kelompokkelompok komunitas, organisasi bisnis lokal dan berbagai asosiasi lokal. Kedua, sebagai local authority (pemerintah lokal), yang keterlibatannya sangat penting karena memiliki tanggung jawab untuk menerapkan kebijakan dan perencanaan, menegakkan peraturan dan melakukan pemantauan pembangunan. Ketiga, sebagai tourism industry (industri pariwisata) yang terdiri dari berbagai subsektor seperti penyedia transportasi, akomodasi, atraksi (alam, budaya atau bangunan, yang meliputi 
museum, fasilitas perbelanjaan, acara budaya atau olahraga, festival dan lain-lain), makanan dan minuman dan biro perjalanan.

Sebagai pemangku kepentingan kunci, masyarakat lokal di negara berkembang seringkali terlibat aktif dalam pengelolaan dan juga dalam menentukan perencanaan dan manajemen pariwisata di destinasi wisata (Mason, 2003: 87). Bahkan tidak jarang masyarakat lokal sudah lebih dahulu terlibat dalam pengelolaan pariwisata sebelum adanya kegiatan pengembangan dan perencanaaan pariwisata (Damanik \& Weber, 2006: 23). Masyarakat lokal ini berorientasi untuk memperoleh kualitas hidup yang lebih baik dan mendapatkan keuntungan ekonomi dari pariwisata (Timur \& Getz, 2009: 222).

Menurut Cárdenas, Byrd \& Duffy (2015: 263) apabila masyarakat di lokal sekitar destinasi wisata mengandalkan pariwisata sebagai sektor pemenuh kebutuhan ekonomi, maka itu tandanya sumber daya alam dan lingkungan sekitar menjadi semakin rentan terhadap eksploitasi berlebihan, sehingga edukasi tentang pariwisata berkelanjutan penting untuk dilakukan. Pariwisata berkelanjutan merupakan pariwisata yang berbasis pembangunan berkelanjutan yang dapat diterapkan pada setiap bentuk pariwisata dan di setiap destinasi wisata, dengan menerapkan keseimbangan dari tiga aspek yaitu lingkungan, ekonomi dan sosial-budaya sehingga dapat menjamin keberlanjutan jangka panjang (UNEP dan WTO, 2005: 11).

Edukasi tentang pariwisata berkelanjutan kepada masyarakat lokal sebagai pemangku kepentingan kunci dalam pengembangan pariwisata berkelanjutan dapat dilakukan dengan mengujikan instrumen SUSTDI (Stakeholder Understanding of Sustainable Tourism Development Index) (Cárdenas, Byrd \& Duffy, 2015). SUSTDI juga dapat menjadi alat untuk mengetahui pengetahuan dan persetujuan mereka terhadap prinsip-prinsip pariwisata berkelanjutan. SUSTDI adalah sebuah studi eksploratif yang berasal dari penelitian milik Cárdenas, Byrd \& Duffy (2015), yang menghasilkan alat penilaian secara kuantitatif yang membantu perencana pariwisata dalam mengukur tingkat pemahaman masyarakat terhadap prinsip-prinsip pariwisata berkelanjutan.

Pengukuran dilakukan dengan cara mengujikan kuesioner SUSTDI yang berisi
31 butir pernyataan yang terbagi ke dalam 6 faktor solusi. Enam faktor solusi tersebut terdiri dari konservasi sumber daya alam (resource preservation) yang memiliki 8 butir pernyataan, edukasi lingkungan (environmental education) 6 butir pernyataan, inklusi pemangku kepentingan (stakeholders inclusion) 6 butir pernyataan, perencanaan ekonomi (economic planning) 6 butir pernyataan, kesadaran budaya (cultural awareness) 2 butir pernyataan dan identifikasi sumber daya masyarakat (community resource identification) sebanyak 3 butir pernyataan. Faktor-faktor di dalam SUSTDI tersebut merupakan penyempurnaan dari faktor-faktor yang mempengaruhi kesadaran pemangku kepentingan yang diadaptasi dari penelitian Byrd, Cárdenas \& Greenwood (2008). Selanjutnya, penyempurnaan faktor solusi pada SUSTDI dikembangkan dari penelitian-penelitian lainnya yang berkaitan dengan teori stakeholder, prinsip pengembangan pariwisata berkelanjutan, persepsi dan sikap penduduk terhadap pariwisata yang disempurnakan dengan saran-saran dari para edukator yang memiliki perhatian lebih terhadap pariwisata berkelanjutan (Cárdenas, Byrd \& Duffy, 2015: 258). Faktor-faktor solusi pada SUSTDI telah mencakup lima dari enam prinsip pengembangan pariwisata berkelanjutan milik Byrd et al (2008) yang tertulis dalam definisi konseptual World Tourism Organization (WTO) kecuali prinsip yang berkaitan dengan kepuasan wisatawan, sehingga dengan demikian SUSTDI tidak dapat diujikan kepada wisatawan.

SUSTDI bermanfaat untuk mengedukasi pemangku kepentingan terkait prinsip-prinsip pariwisata berkelanjutan melalui setiap butir pernyataan yang diujikan. Hasil penilaian SUSTDI dapat digunakan untuk mengembangkan program pendidikan dan pelatihan dalam rangka meningkatkan pemahaman dan pengetahuan pemangku kepentingan terhadap prinsip-prinsip pariwisata berkelanjutan. Program pendidikan dan pelatihan tersebut akan fokus pada faktorfaktor yang memiliki tingkat pemahaman yang rendah ataupun yang memiliki ketimpangan. Penilaian SUSTDI pada pemangku kepentingan sangat diperlukan sebab tingkat pemahaman yang baik terhadap prinsip-prinsip pariwisata berkelanjutan akan mengarah pada perbaikan produk dan pelayanan bagi semua yang terlibat 
dalam destinasi wisata (Cárdenas, Byrd \& Duffy, 2015). Dengan demikian, masyarakat lokal sebagai pemangku kepentingan kunci dalam perencanaan dan manajemen destinasi wisata adalah sasaran yang tepat dalam mengujikan SUSTDI.

\section{Metodologi Penelitian}

Penelitian ini merupakan penelitian kuantitatif deskriptif yang bertujuan untuk menjelaskan, meringkaskan berbagai kondisi, berbagai situasi dan variabel yang menjadi objek penelitian berdasarkan apa yang terjadi (Bungin, 2005: 44). Penelitian ini juga dimaksudkan untuk mendeskripsikan situasi atau kejadian secara tepat dan akurat, bukan untuk mencari hubungan sebab dan akibat (Yusuf, 2013: 63). Pengumpulan data dilakukan dengan menyebarkan kuesioner kepada 64 responden representatif dengan menggunakan teknik proporsional sampling, sehingga dapat diketahui tiga kelompok masyarakat lokal yang berperan sebagai pemangku kepentingan kunci di Tebing Breksi Yogyakarta. Tiga kelompok pemangku kepentingan kunci tersebut adalah Kelompok Pemerintah Desa Sambirejo, Kelompok Komunitas Lokal yang terdiri dari yang terdiri dari Kelompok Sadar Wisata Tlatar Seneng dan Kelompok Pengelola Tebing Breksi Lowo Ijo dan Kelompok Penyedia Jasa Lokal yang meliputi meliputi penyedia kuliner, penyedia jasa photo booth Enliven dan kelompok penyedia jip wisata Shiva Plateau.

Penentuan sampel pada setiap kelompok kemudian dilakukan dengan cara stratified random sampling agar sampel antar kelompok tidak tumpang tindih satu sama lain. Implementasi teknik stratified random sampling dalam peneltian ini dilakukan dengan cara membuat daftar nama sampel yang terpilih yang menjadi responden penelitian. Pembuatan daftar nama sampel yang terpilih didasarkan dari daftar nama pada struktur organisasi di setiap kelompok pemangku kepentingan kunci yang didapatkan dari hasil observasi dan wawancara peneliti. Peneliti kemudian memilih siapa saja sampel yang memiliki posisi penting dalam struktur organisasi seperti Ketua, Sekeretaris, Bendahara dan Anggota yang tidak tumpang tindih satu sama lain. Menurut Yusuf (2014: 160-161), penggunaan teknik stratified random sampling dimaksudkan untuk memperkecil kesalahan dalam menentukan sampling (sampling error) dan untuk menambahkan keterwakilan (representativeness) pada sampel yang diambil.

Analisis data dilakukan dengan mencari nilai rata-rata (mean score) yang diperoleh dari menghitung frekuensi (fi) jawaban dari setiap responden, dikalikan dengan nilai bobot (xi) pada setiap respon jawaban. Nilai bobot pada setiap respon jawaban adalah: "Sangat Tidak Setuju (STS) memiliki nilai bobot 1, "Tidak Setuju (TS)" nilai bobot 2, "Ragu-Ragu (RR)" nilai bobot 3, "Setuju (S)" nilai bobot 4 dan "Sangat Setuju (SS)" dengan nilai bobot 5 .

$$
\bar{x}=\frac{\Sigma f i X i}{n}
$$

Keterangan:

$$
\begin{aligned}
\bar{x} & =\text { rata-rata } \\
f i & =\text { frekuensi data yang ke } \mathrm{i} \\
f i X i & =\text { perkalian frekuensi dengan nilai bobot } \mathrm{i} \\
n & =\text { jumlah individu i } \\
\Sigma f i X \mathrm{i} & =\text { jumlah perkalian frekuensi dengan nilai } \\
& \text { bobot data ke } \mathrm{i}
\end{aligned}
$$

Nilai rata-rata (mean score) yang telah diperoleh selanjutnya dinalisis secara deskriptif melalui dasar pengklasifikasian mengacu pada ketentuan yang dikemukakan oleh Umar (1998), yaitu Rentang Skala (RS) yang diperoleh dengan formula sebagai berikut:

$$
R S=\frac{m-1}{m}
$$

Keterangan: $m=$ jumlah alternatif jawaban tiap butir pernyataan

Sehingga,

Tabel 1. Interpretasi Skala Penilaian

\begin{tabular}{|c|c|}
\hline Skala Penilaian & Kriteria \\
\hline $1,00-1,80$ & Sangat rendah \\
\hline $1,80-2,60$ & Rendah \\
\hline $2,60-3,40$ & Sedang \\
\hline $3,40-4,20$ & Tinggi \\
\hline $4,20-5,00$ & Sangat tinggi \\
\hline
\end{tabular}

Sumber: Umar (1998) 
Berdasarkan skala penilaian di atas, jika nilai rata-rata yang diperoleh pada masing-masing butir pernyataan yang ada di setiap faktor solusi semakin mendekati angka 5,00, maka semakin tinggi tingkat pemahaman pemangku kepentingan kunci di Tebing Breksi terhadap pernyataan tersebut. Sebaliknya, apabila nilai rata-rata semakin mendekati angka 1,00, maka tingkat pemahaman pemangku kepentingan kunci di Tebing Breksi semakin rendah. Selanjutnya dalam menentukan nilai rata-rata pada setiap faktor, dilakukan dengan menjumlah setiap nilai rata-rata pada setiap butir pernyataan dibagi jumlah pernyataan secara keseluruhan di setiap faktor. Berdasarkan interpretasi skala penilaian pada Tabel 1, akan diketahui tingkat pemahaman pemangku kepentingan kunci pada setiap faktor sehingga dapat diketahui faktor apa saja yang memerlukan perhatian lebih dalam menyusun program edukasi untuk pengembangan pariwisata berkelanjutan di Tebing Breksi.

\section{Hasil Penelitian}

\subsection{Deskripsi Karakteristik Responden}

Karakteristik responden yang merupakan masyarakat lokal yang menjadi pemangku kepentingan kunci di Tebing Breksi mayoritas berusia 23-39 tahun, sudah menikah, berjenis kelamin laki-laki,berlatar pendidikan sebagai lulusan SMA dengan tingat pendapatan yang rendah (BPS:2008) dan di bawah UMR DIY karena memiliki tingkat pendapatan perbulan kurang dari Rp1.500.00,00. Apabila dilihat dari sisi peran, ditemukan perbedaan jumlah antara data peran berdasarkan data pada struktur organisasi dan peran yang dipilih oleh setiap individu sehingga hal ini mengindikasikan adanya peran ganda pada pemangku kepentingan kunci di Tebing Breksi.

Tabel 2. Karakteristik Responden

\begin{tabular}{|c|c|c|}
\hline Karakteristik & $\mathrm{n}$ & $\%$ \\
\hline \multicolumn{3}{|c|}{ Usia } \\
\hline 15-24 tahun & 17 & $26,6 \%$ \\
\hline 25-39 tahun & 29 & $45,3 \%$ \\
\hline $40-55$ tahun & 16 & $25,0 \%$ \\
\hline 56-64 tahun & 1 & $1,6 \%$ \\
\hline$>64$ tahun & 1 & $1,6 \%$ \\
\hline
\end{tabular}

\begin{tabular}{|c|c|c|}
\hline \multicolumn{3}{|l|}{ Status Pernikahan } \\
\hline Belum Menikah & 19 & $29,7 \%$ \\
\hline Menikah & 45 & $70,3 \%$ \\
\hline \multicolumn{3}{|l|}{ Jenis Kelamin } \\
\hline Laki-Laki & 54 & $84,4 \%$ \\
\hline Perempuan & 10 & $15,6 \%$ \\
\hline \multicolumn{3}{|l|}{ Tingkat Pendidikan } \\
\hline Tidak Bersekolah Formal & & $0,0 \%$ \\
\hline Tidak Tamat SD & 0 & $0,0 \%$ \\
\hline Tamat SD & 6 & $9,4 \%$ \\
\hline Tamat SMP/MTs & 21 & $32,8 \%$ \\
\hline Tamat SMA/SMK & 30 & $46,9 \%$ \\
\hline Perguruan Tinggi & 7 & $10,9 \%$ \\
\hline \multicolumn{3}{|c|}{ Tingkat Pendapatan per Bulan } \\
\hline$<$ Rp1.500.000,00 & 48 & $75,0 \%$ \\
\hline Rp1.500.000,00 - Rp2.500.000,00 & 13 & $20,3 \%$ \\
\hline Rp2.500.000,00 - Rp3.500.000,00 & 2 & $3,1 \%$ \\
\hline > Rp3.500.000,00 & 1 & $1,6 \%$ \\
\hline \multicolumn{3}{|l|}{ Peran } \\
\hline Sebagai Pemerintah Desa & 7 & $10,9 \%$ \\
\hline Sebagai Komunitas Lokal & 23 & $35,9 \%$ \\
\hline Sebagai Penyedia Jasa Lokal & 34 & $53,1 \%$ \\
\hline
\end{tabular}

\subsection{Analisis Kuesioner SUSTDI}

Hasil analisis kuesioner SUSTDI di tiga kelompok pemangku kepentingan kunci pada Tabel 3 secara keseluruhan menunjukkan hasil yang baik dengan interpretasi tingkat pemahaman pada setiap butir pernyataan menunjukan kategori "Tinggi" hingga "Sangat Tinggi". Hasil ini menunjukkan bahwa secara mayoritas responden memberikan respon jawaban positif yaitu "Sangat Setuju" maupun "Setuju" terhadap 31 pernyataan yang diajukan.

Walapun demikian, masih terdapat beberapa butir pernyataan yang memiliki tingkat pemahaman yang "Rendah" dan "Sedang". Tingkat pemahaman yang "Rendah" ditunjukkan oleh Kelompok Penyedia Jasa terhadap pernyataan pada nomor 4 yang menyatakan bahwa "pariwisata harus tidak dilanjutkan apabila merusak lingkungan" dengan nilai rata-rata 2,57 . Sehubungan dengan rendahnya tingkat pemahaman pada pernyataan nomor 4 , maka diperlukan upaya untuk meningkatkan pemahaman Kelompok Penyedia Jasa Lokal sebagai bagian dari pemangku kepentingan kunci di Tebing Breksi 
Tabel 3. Analisis Kuesioner SUSTDI pada Tiga Kelompok Pemangku Kepentingan Kunci

\begin{tabular}{|c|c|c|c|c|c|c|c|}
\hline \multirow{3}{*}{ No } & \multirow{3}{*}{ Pernyataan } & \multicolumn{6}{|c|}{ Kelompok pada StakeholderKunci Lokal } \\
\hline & & \multicolumn{2}{|c|}{$\begin{array}{l}\text { Pemerintah } \\
\text { Desa }\end{array}$} & \multicolumn{2}{|c|}{$\begin{array}{l}\text { Komunitas } \\
\text { Lokal }\end{array}$} & \multicolumn{2}{|c|}{$\begin{array}{l}\text { Penyedia } \\
\text { Jasa Lokal }\end{array}$} \\
\hline & & $\begin{array}{l}\text { Mean } \\
\text { Score }\end{array}$ & Ket. & $\begin{array}{l}\text { Mean } \\
\text { Score }\end{array}$ & Ket. & $\begin{array}{l}\text { Mean } \\
\text { Score }\end{array}$ & Ket. \\
\hline \multicolumn{8}{|c|}{ Faktor 1. Konservasi Sumber Daya Alam } \\
\hline 1 & $\begin{array}{l}\text { Pengembangan pariwisata harus mencakup } \\
\text { perlindungan terhadap lingkungan alam }\end{array}$ & 4,00 & Tinggi & 4,57 & $\begin{array}{l}\text { Sangat } \\
\text { Tinggi }\end{array}$ & 4,47 & $\begin{array}{l}\text { Sangat } \\
\text { Tinggi }\end{array}$ \\
\hline 2 & $\begin{array}{l}\text { Studi mengenai dampak lingkungan harus } \\
\text { dilakukan untuk pengembangan pariwisata } \\
\text { yang ada dan yang telah diusulkan }\end{array}$ & 4,00 & Tinggi & 4,14 & Tinggi & 4,13 & Tinggi \\
\hline 3 & $\begin{array}{l}\text { Kegiatan pariwisata harus diintegrasikan } \\
\text { (digabungkan menjadi satu kesatuan) } \\
\text { dengan program konservasi daerah }\end{array}$ & 4,17 & Tinggi & 3,86 & Tinggi & 4,13 & Tinggi \\
\hline 4 & $\begin{array}{l}\text { Pengembangan pariwisata harus tidak } \\
\text { dilanjutkan apabila merugikan lingkungan }\end{array}$ & 4,00 & Tinggi & 3,39 & Sedang & 2,57 & Rendah \\
\hline 5 & $\begin{array}{l}\text { Pariwisata harus membuat lingkungan } \\
\text { menjadi lebih baik untuk generasi mendatang }\end{array}$ & 4,33 & $\begin{array}{l}\text { Sangat } \\
\text { Tinggi }\end{array}$ & 4,64 & $\begin{array}{l}\text { Sangat } \\
\text { Tinggi }\end{array}$ & 4,73 & $\begin{array}{l}\text { Sangat } \\
\text { Tinggi }\end{array}$ \\
\hline 6 & $\begin{array}{l}\text { Pariwisata seharusnya tidak } \\
\text { diperbolehkan untuk merusak sumber } \\
\text { daya budaya (cagar budaya) }\end{array}$ & 4,83 & $\begin{array}{l}\text { Sangat } \\
\text { Tinggi }\end{array}$ & 4,43 & $\begin{array}{l}\text { Sangat } \\
\text { Tinggi }\end{array}$ & 4,13 & Tinggi \\
\hline 7 & $\begin{array}{l}\text { Sumber Daya Alam harus dilindungi untuk } \\
\text { digunakan oleh generasi mendatang }\end{array}$ & 5,00 & $\begin{array}{l}\text { Sangat } \\
\text { Tinggi }\end{array}$ & 4,57 & $\begin{array}{l}\text { Sangat } \\
\text { Tinggi }\end{array}$ & 4,50 & $\begin{array}{l}\text { Sangat } \\
\text { Tinggi }\end{array}$ \\
\hline 8 & $\begin{array}{l}\text { Masyarakat harus terlibat secara aktif } \\
\text { dalam pelestarian lingkungan hidup } \\
\text { di wilayah ini (Tebing Breksi) }\end{array}$ & 4,50 & $\begin{array}{l}\text { Sangat } \\
\text { Tinggi }\end{array}$ & 4,39 & $\begin{array}{l}\text { Sangat } \\
\text { Tinggi }\end{array}$ & 4,60 & $\begin{array}{l}\text { Sangat } \\
\text { Tinggi }\end{array}$ \\
\hline \multicolumn{8}{|c|}{ Faktor 2. Edukasi Lingkungan } \\
\hline 9 & $\begin{array}{l}\text { Diperlukan kesempatan untuk mempelajari } \\
\text { lebih lanjut tentang lingkungan alam }\end{array}$ & 4,17 & Tinggi & 4,00 & Tinggi & 3,97 & Tinggi \\
\hline 10 & $\begin{array}{l}\text { Program pendidikan lingkungan } \\
\text { mengarah pada peningkatan } \\
\text { pemanfaatan sumber daya alam }\end{array}$ & 4,33 & $\begin{array}{l}\text { Sangat } \\
\text { Tinggi }\end{array}$ & 3,96 & Tinggi & 4,00 & Tinggi \\
\hline 11 & $\begin{array}{l}\text { Tanaman dan hewan memiliki } \\
\text { hak selayaknya manusia terhadap } \\
\text { sumber daya alam di lingkungan } \\
\text { dan masyarakat sekitarnya }\end{array}$ & 4,17 & Tinggi & 4,18 & Tinggi & 4,17 & Tinggi \\
\hline 12 & $\begin{array}{l}\text { Pendidikan terhadap penduduk setempat } \\
\text { tentang praktik penggunaan lahan yang } \\
\text { tepat sangat penting bagi keberhasilan } \\
\text { pengembangan pariwisata di Tebing Breksi }\end{array}$ & 4,17 & Tinggi & 4,21 & $\begin{array}{l}\text { Sangat } \\
\text { Tinggi }\end{array}$ & 4,20 & Tinggi \\
\hline 13 & $\begin{array}{l}\text { Pendidikan terhadap pemilik bisnis } \\
\text { lokal tentang praktik penggunaan } \\
\text { lahan yang tepat sangat penting bagi } \\
\text { keberhasilan pengembangan pariwisata }\end{array}$ & 4,17 & Tinggi & 4,11 & Tinggi & 3,97 & Tinggi \\
\hline
\end{tabular}




\begin{tabular}{|c|c|c|c|c|c|c|c|}
\hline 14 & $\begin{array}{l}\text { Pendidikan terhadap pengunjung } \\
\text { tentang praktik penggunaan lahan yang } \\
\text { tepat sangat penting bagi keberhasilan } \\
\text { pengembangan pariwisata di Tebing Breksi }\end{array}$ & 3,83 & Tinggi & 3,61 & Tinggi & 4,17 & Tinggi \\
\hline \multicolumn{8}{|c|}{ Faktor 3. Inklusi Pemangku Kepentingan } \\
\hline 15 & $\begin{array}{l}\text { Para pemimpin sektor pariwisata harus } \\
\text { memantau kepuasan pengusaha di bidang } \\
\text { bisnis pariwisata dengan sudut pandang } \\
\text { pariwisata agar pariwisata menjadi sukses }\end{array}$ & 4,17 & Tinggi & 4,11 & Tinggi & 4,27 & $\begin{array}{l}\text { Sangat } \\
\text { Tinggi }\end{array}$ \\
\hline 16 & $\begin{array}{l}\text { Para pemimpin sektor pariwisata harus } \\
\text { memantau kepuasan warga di kawasan } \\
\text { pariwisata agar pariwisata menjadi sukses }\end{array}$ & 4,67 & $\begin{array}{l}\text { Sangat } \\
\text { Tinggi }\end{array}$ & 4,25 & $\begin{array}{l}\text { Sangat } \\
\text { Tinggi }\end{array}$ & 4,27 & $\begin{array}{l}\text { Sangat } \\
\text { Tinggi }\end{array}$ \\
\hline 17 & $\begin{array}{l}\text { Keterlibatan masyarakat meningkatkan } \\
\text { dukungan bagi sektor pariwisata }\end{array}$ & 4,33 & $\begin{array}{l}\text { Sangat } \\
\text { Tinggi }\end{array}$ & 4,32 & $\begin{array}{l}\text { Sangat } \\
\text { Tinggi }\end{array}$ & 4,43 & $\begin{array}{l}\text { Sangat } \\
\text { Tinggi }\end{array}$ \\
\hline 18 & $\begin{array}{l}\text { Para pemimpin pariwisata harus memantau } \\
\text { kepuasan wisatawan dengan sudut pandang } \\
\text { pariwisata agar pariwisata menjadi sukses }\end{array}$ & 4,50 & $\begin{array}{l}\text { Sangat } \\
\text { Tinggi }\end{array}$ & 3,89 & Tinggi & 4,33 & $\begin{array}{l}\text { Sangat } \\
\text { Tinggi }\end{array}$ \\
\hline 19 & $\begin{array}{l}\text { Partisipasi pengunjung dalam pengembangan } \\
\text { pariwisata sangat penting bagi } \\
\text { keberhasilan pengembangan pariwisata }\end{array}$ & 4,17 & Tinggi & 4,11 & Tinggi & 4,43 & $\begin{array}{l}\text { Sangat } \\
\text { Tinggi }\end{array}$ \\
\hline 20 & $\begin{array}{l}\text { Partisipasi masyarakat dalam pengembangan } \\
\text { pariwisata sangat penting bagi } \\
\text { keberhasilan pengembangan pariwisata }\end{array}$ & 4,17 & Tinggi & 4,29 & $\begin{array}{l}\text { Sangat } \\
\text { Tinggi }\end{array}$ & 4,43 & $\begin{array}{l}\text { Sangat } \\
\text { Tinggi }\end{array}$ \\
\hline \multicolumn{8}{|c|}{ Faktor 4. Perencanaan Ekonomi } \\
\hline 21 & $\begin{array}{l}\text { Pariwisata memberikan keanekaragaman } \\
\text { bagi ekonomi lokal }\end{array}$ & 4,50 & $\begin{array}{l}\text { Sangat } \\
\text { Tinggi }\end{array}$ & 4,25 & $\begin{array}{l}\text { Sangat } \\
\text { Tinggi }\end{array}$ & 4,23 & $\begin{array}{l}\text { Sangat } \\
\text { Tinggi }\end{array}$ \\
\hline 22 & $\begin{array}{l}\text { Pariwisata itu baik untuk } \\
\text { ekonomi masyarakat }\end{array}$ & 4,17 & Tinggi & 4,25 & $\begin{array}{l}\text { Sangat } \\
\text { Tinggi }\end{array}$ & 4,30 & $\begin{array}{l}\text { Sangat } \\
\text { Tinggi }\end{array}$ \\
\hline 23 & $\begin{array}{l}\text { Dana pembangunan ekonomi sebaiknya } \\
\text { digunakan untuk mempromosikan pariwisata }\end{array}$ & 2,83 & Sedang & 3,36 & Sedang & 3,33 & Sedang \\
\hline 24 & $\begin{array}{l}\text { Tujuan jangka panjang diperlukan } \\
\text { ketika akan merencanakan } \\
\text { pengembangan pariwisata }\end{array}$ & 4,00 & Tinggi & 4,36 & $\begin{array}{l}\text { Sangat } \\
\text { Tinggi }\end{array}$ & 4,27 & $\begin{array}{l}\text { Sangat } \\
\text { Tinggi }\end{array}$ \\
\hline 25 & $\begin{array}{l}\text { Saya percaya pengembangan pariwisata } \\
\text { membutuhkan perencanaan yang } \\
\text { terkoordinasi dengan baik }\end{array}$ & 4,50 & $\begin{array}{l}\text { Sangat } \\
\text { Tinggi }\end{array}$ & 4,36 & $\begin{array}{l}\text { Sangat } \\
\text { Tinggi }\end{array}$ & 4,40 & $\begin{array}{l}\text { Sangat } \\
\text { Tinggi }\end{array}$ \\
\hline 26 & $\begin{array}{l}\text { Pendidikan terhadap pejabat pemerintah } \\
\text { daerah tentang praktik penggunaan } \\
\text { lahan yang tepat sangat penting bagi } \\
\text { keberhasilan pengembangan pariwisata }\end{array}$ & 4,17 & Tinggi & 4,04 & Tinggi & 3,83 & Tinggi \\
\hline \multicolumn{8}{|c|}{$\begin{array}{ll}\text { Faktor 5. Kesadaran Budaya } \\
\end{array}$} \\
\hline 27 & $\begin{array}{l}\text { Kesempatan dibutuhkan untuk belajar } \\
\text { lebih banyak tentang sejarah setempat }\end{array}$ & 4,17 & Tinggi & 4,11 & Tinggi & 4,27 & $\begin{array}{l}\text { Sangat } \\
\text { Tinggi }\end{array}$ \\
\hline 28 & $\begin{array}{l}\text { Kesempatan dibutuhkan untuk belajar } \\
\text { lebih banyak tentang budaya lokal }\end{array}$ & 4,33 & $\begin{array}{l}\text { Sangat } \\
\text { Tinggi }\end{array}$ & 4,18 & Tinggi & 4,30 & $\begin{array}{l}\text { Sangat } \\
\text { Tinggi }\end{array}$ \\
\hline
\end{tabular}




\begin{tabular}{|c|l|c|c|c|c|c|c|}
\hline \multicolumn{2}{|c|}{ Faktor 6. Identifikasi Sumber Daya Manusia } \\
\hline 29 & $\begin{array}{l}\text { Budaya masyarakat merupakan } \\
\text { daya tarik wisata }\end{array}$ & 4,67 & $\begin{array}{l}\text { Sangat } \\
\text { Tinggi }\end{array}$ & 4,39 & Tinggi & 4,27 & $\begin{array}{c}\text { Sangat } \\
\text { Tinggi }\end{array}$ \\
\hline 30 & $\begin{array}{l}\text { Pemugaran terhadap situs sejarah } \\
\text { akan mempromosikan pariwisata }\end{array}$ & 3,83 & Tinggi & 3,71 & Tinggi & 4,30 & $\begin{array}{c}\text { Sangat } \\
\text { Tinggi }\end{array}$ \\
\hline 31 & Lingkungan alam adalah daya tarik wisata & 4,50 & $\begin{array}{l}\text { Sangat } \\
\text { Tinggi }\end{array}$ & 4,36 & $\begin{array}{l}\text { Sangat } \\
\text { Tinggi }\end{array}$ & 4,30 & $\begin{array}{l}\text { Sangat } \\
\text { Tinggi }\end{array}$ \\
\hline
\end{tabular}

bahwa pariwisata tidak dapat dilakukan tanpa batas dan tidak boleh merusak sumber daya yang ada serta harus berorientasi untuk meminimalkan dampak serta memaksimalkan manfaat bagi lingkungan alam dan masyarakat lokal (UNWTO, 2004:3).

Kelompok Komunitas Lokal memiliki tingkat pemahaman yang "Sedang" terhadap pernyataan pada nomor 4 dengan nilai rata-rata 3,39. Dengan tingkat pemahaman yang sedang, maka diperlukan upaya lebih lanjut untuk memberikan pemahaman kepada Kelompok Komunitas Lokal terkait dengan apa dan bagaimana konservasi sumber daya alam yang seharusnya dilakukan. Menurut Fandeli (2002), salah satu bentuk konsevasi sumber daya alam di destinasi wisata dapat dilakukan dengan melakukan pengusahaan ekowisata. Ekowisata merupakan suatu bentuk wisata yang mengadopsi prinsip-prinsip pariwisata berkelanjutan dengan menyediakan bentuk kegiatan wisata yang secara aktif menyumbang kegiatan konservasi alam dan budaya, melibatkan masyarakat lokal dalam perencanaan, pengembangan dan pengelolaan wisata serta memberikan sembangan positif terhadap kesejahteraan mereka yang dilakukan dalam bentuk kelompok kecil (Deklarasi Quebec dalam Damanik \& Weber, 2006: 38).

Sedangkan pernyataan pada nomor 23 yang menyatakan bahwa "dana pembangunan ekonomi sebaiknya digunakan untuk memajukan pariwisata", di ketiga kelompok pemangku kepentingan kunci menunjukkan tingkat pemahaman yang "Sedang". Dalam hubungan ini, artinya ketiga kelompok pemangku kepentingan kunci di Tebing Breksi memiliki tingkat pemahaman yang sedang pada hal-hal yang berkaitan dengan penggunaan dana ekonomi untuk pengembangan pariwisata.

Dalam mencapai keberhasilan pengembangan pariwisata yang berkelanjutan, aspek ekonomi adalah satu dari tiga aspek penting dalam, selain aspek lingkungan dan sosial-budaya (Hitchcock and Willard, 2009; Stoddard et al., 2012; Swarbrook, 1999: dalam Cárdenas, Byrd \& Duffy, 2015:255). Menurut Hitchcock and Willard (2009:9) dalam Cárdenas, Byrd \& Duffy (2015:255), ketika pemangku kepentingan tidak memahami 3 (tiga) aspek penting yang saling berinterdependensi tersebut, biasanya mereka cenderung membuat keputusan yang kurang tepat dalam upayanya mencapai pengembangan pariwisata yang berkelanjutan.

\subsection{Analisis Tingkat Pemahaman Masyarakat Lokal sebagai Pemangku Kepentingan di Tebing Breksi Kunci terhadap Prinsip-Prinsip Pariwisata Berkelanjutan berdasarkan SUSTDI}

Hasil analisis pada Tabel 4 menunjukkan bahwa masyarakat lokal sebagai pemangku kepentingan kunci di Tebing Breksi memiliki tingkat pemahaman yang tinggi terhadap prinsip-prinsip pariwisata berkelanjutan dengan nilai rata-rata 4,19. Dengan demikian, dapat disimpulkan bahwa masyarakat lokal sebagai pemangku kepentingan kunci cenderung memberikan persetujuannya terhadap butir-butir pernyataan SUSTDI yang di dalamnya memuat prinsip-prinsip pariwisata berkelanjutan. Persetujuan ini kemudian dapat diartikan bahwa mereka paham pentingnya melaksanakan pariwisata di Tebing Breksi sebagaimana seperti yang tertera pada 31 butir pernyataan yang diajukan kepada responden.

Meskipun secara keseluruhan memiliki tingkat pemahaman yang baik terhadap prinsipprinsip pariwisata berkelanjutan, tingkat pemahaman pada setiap kelompok pemangku kepentingan kunci tidak dapat digeneralisasikan. Seperti yang terjadi pada nilai rata-rata di Kelompok Pemerintah Desa Sambirejo terhadap SUSTDI sebesar 4,24 yang lebih tinggi daripada Kelompok Komunitas Lokal 
Tabel 4. Tingkat Pemahaman Pemangku Kepentingan Kunci di Tebing Breksi

\begin{tabular}{|c|c|c|c|c|c|c|c|c|c|}
\hline \multirow{3}{*}{ No } & \multirow{3}{*}{ Faktor } & \multicolumn{6}{|c|}{ Kelompok Pemangku Kepentingan Kunci } & \multirow{3}{*}{$\begin{array}{c}\text { Total } \\
\text { Mean } \\
\text { Score }\end{array}$} & \multirow{3}{*}{ Ket. } \\
\hline & & \multicolumn{2}{|c|}{$\begin{array}{c}\text { Pemerintah } \\
\text { Desa }\end{array}$} & \multicolumn{2}{|c|}{$\begin{array}{c}\text { Komunitas } \\
\text { Lokal }\end{array}$} & \multicolumn{2}{|c|}{$\begin{array}{c}\text { Penyedia } \\
\text { Jasa Lokal }\end{array}$} & & \\
\hline & & $\begin{array}{l}\text { Mean } \\
\text { Score }\end{array}$ & Ket. & $\begin{array}{l}\text { Mean } \\
\text { Score }\end{array}$ & Ket. & $\begin{array}{l}\text { Mean } \\
\text { Score }\end{array}$ & Ket. & & \\
\hline 1 & $\begin{array}{l}\text { Konservasi Sumber } \\
\text { Daya Alam }\end{array}$ & 4,35 & $\begin{array}{l}\text { Sangat } \\
\text { Tinggi }\end{array}$ & 4,25 & $\begin{array}{l}\text { Sangat } \\
\text { Tinggi }\end{array}$ & 4,16 & Tinggi & 4,25 & $\begin{array}{l}\text { Sangat } \\
\text { Tinggi }\end{array}$ \\
\hline 2 & Edukasi Lingkungan & 4,14 & Tinggi & 4,01 & Tinggi & 4,08 & Tinggi & 4,08 & Tinggi \\
\hline 3 & $\begin{array}{l}\text { Inklusi Pemangku } \\
\text { kepentingan }\end{array}$ & 4,33 & $\begin{array}{l}\text { Sangat } \\
\text { Tinggi } \\
\end{array}$ & 4,16 & Tinggi & 4,36 & $\begin{array}{l}\text { Sangat } \\
\text { Tinggi } \\
\end{array}$ & 4,29 & $\begin{array}{l}\text { Sangat } \\
\text { Tinggi } \\
\end{array}$ \\
\hline 4 & Perencanaan Ekonomi & 4,03 & Tinggi & 4,10 & Tinggi & 4,06 & Tinggi & 4,06 & Tinggi \\
\hline 5 & Kesadaran Budaya & 4,25 & $\begin{array}{l}\text { Sangat } \\
\text { Tinggi }\end{array}$ & 4,14 & Tinggi & 4,28 & $\begin{array}{l}\text { Sangat } \\
\text { Tinggi }\end{array}$ & 4,23 & $\begin{array}{l}\text { Sangat } \\
\text { Tinggi }\end{array}$ \\
\hline 6 & $\begin{array}{l}\text { Identifikasi sumber } \\
\text { daya masyarakat }\end{array}$ & 4,33 & $\begin{array}{l}\text { Sangat } \\
\text { Tinggi }\end{array}$ & 4,15 & Tinggi & 4,29 & $\begin{array}{l}\text { Sangat } \\
\text { Tinggi }\end{array}$ & 4,26 & $\begin{array}{l}\text { Sangat } \\
\text { Tinggi }\end{array}$ \\
\hline & Mean Score SUSTDI & 4,24 & $\begin{array}{l}\text { Sangat } \\
\text { Tinggi }\end{array}$ & 4,14 & Tinggi & 4,20 & Tinggi & 4,19 & Tinggi \\
\hline
\end{tabular}

yang memiliki nilai rata-rata 4,14 dan Kelompok Penyedia Jasa Lokal dengan nilai rata-rata 4,20. Hal ini dapat menunjukkan bahwa Kelompok Pemerintah Desa Sambirejo lebih memahami pentingnya prinsip-prinsip pariwisata berkelanjutan dibandingkan dua kelompok pemangku kepentingan kunci lainnya.

Berdasarkan analisis pada setiap faktor, terlihat perbedaan nilai rata-rata dan tingkat pemahaman di setiap kelompok responden. Pada faktor konservasi sumber daya alam nilai rata-rata tertinggi diperoleh oleh Kelompok Pemerintah Desa Sambirejo dengan nilai 4,35. Hal ini menunjukkan bahwa Kelompok Pemerintah Desa Sambirejo memiliki tingkat persetujuan yang lebih tinggi terhadap faktor konservasi lingkungan alam daripada Kelompok Komunitas Lokal dan Kelompok Penyedia Jasa Lokal di Tebing Breksi. Hal ini menunjukkan bahwa Kelompok Pemerintah Desa Sambirejo lebih memahami pentingnya faktor konservasi sumber daya alam daripada dua kelompok pemangku kepentingan kunci lainnya. Faktor koservasi sumber daya alam adalah faktor prioritas dalam pengembangan pariwisata berkelanjutan yang bertujuan untuk mengoptimalkan penggunaan sumber daya lingkungan secara bertanggungjawab (UNWTO, 2004:5).
Sementara pada faktor edukasi lingkungan, Kelompok Komunitas Lokal memperoleh nilai rata-rata terendah dengan nilai 4,01. Hal ini mengindikasikan bahwa perlu menyediakan kesempatan lebih bagi Kelompok Komunitas Lokal untuk belajar tentang pendidikan lingkungan. Menurut Sakellari \& Skavanis (2013: 322), program pendidikan lingkungan harus dirancang secara efektif dengan mempertimbangkan motivasi, perbedaan sikap dan perliku para pemangku kepentingan dalam belajar.

Sama seperti faktor edukasi lingkungan, pada beberapa faktor berikutnya yaitu faktor inklusi pemangku kepentingan, kesadaran budaya dan identifikasi sumber daya masyarakat, nilai rata-rata terendah masih berada pada Kelompok Komunitas Lokal. Hal ini mengindikasikan bahwa perlu lebih melibatkan, menginformasikan dan memberikan kesempatan kepada Kelompok Komunitas Lokal untuk berpartisipasi dalam upaya pengembangan pariwisata berkelanjutan (Byrd, 2007:8). Sedangkan untuk faktor perencanaan ekonomi, nilai rata-rata terendah ditunjukkan oleh Kelompok Pemerintah Desa Sambirejo.

Secara keseluruhan, faktor perencanaan ekonomi menjadi faktor yang memiliki nilai ratarata terendah diantara 5 faktor lainnya dengan nilai 
4,06. Hal ini menunjukkan bahwa masyarakat lokal sebagai pemangku kepentingan kunci di Tebing Breksi kurang menganggap pentingnya faktor perencanaan ekonomi di dalam melaksankan prinsip-prinsip pariwisata berkelanjutan di Tebing Breksi. Apabila dikaitkan dengan hasil analisis kuesioner pada 4.2, dapat terlihat bahwa ketiga kelompok responden memiliki tingkat pemahaman yang sedang terhadap pernyataan pada nomor 23. Tingkat pemahaman yang sedang tersebut menunjukkan bahwa masyarakat lokal sebagai pemangku kepentingan kunci di Tebing Breksi cenderung ragu-ragu apabila dana pembangunan ekonomi sebaiknya digunakan untuk memajukan pariwisata.

Dengan demikian dapat disimpulkan bahwa faktor perencanaan ekonomi perlu mendapatkan perhatian lebih lanjut karena dalam mencapai keberhasilan pariwisata yang berkelanjutan, aspek ekonomi adalah satu dari tiga aspek penting, selain aspek lingkungan dan sosial-budaya (Hitchcock et al., 2009; Stoddard et al., 2012; Swarbrook, 1999: dalam Cárdenas, Byrd \& Duffy, 2015:255). Menurut Hitchcock et al (2009:9) dalam Cárdenas, Byrd \& Duffy (2015:255), ketika pemangku kepentingan tidak memahami tiga aspek penting yang saling berinterdependensi tersebut, biasanya mereka cenderung membuat keputusan yang kurang tepat dalam upayanya mencapai pengembangan pariwisata yang berkelanjutan.

\section{Kesimpulan dan Rekomendasi}

Kawasan Objek Wisata Taman Tebing Breksi (Tlatar Seneng) Yogyakarta merupakan destinasi wisata yang tumbuh karena fenomena wisata digital. Sejak viral di media sosial terutama Instagram pada tahun 2014, terjadi transformasi pekerjaan pada masyarakat lokal yang dahulu berprofesi sebagai penambang menjadi pemangku kepentingan kunci dalam pengelolaan dan pengembangan pariwisata di Tebing Breksi Yogyakarta. Hal ini membuat masyarakat lokal mengandalkan pariwisata sebagai sektor utama pemenuh kebutuhan ekonomi sehingga dikhawatirkan sumber daya alam dan lingkungan sekitar menjadi semakin rentan terhadap eksploitasi berlebihan. Oleh sebab itu, edukasi tentang prinsipprinsip pariwisata berkelanjutan penting untuk diberikan sebagai upaya menanggulangi dampak- dampak yang akan dihasilkan. Edukasi tentang pariwisata berkelanjutan dapat dilakukan dengan mengujikan instrumen SUSTDI (Stakeholder Understanding of Sustainable Tourism Development Index). Dengan mengujikan SUSTDI, maka dapat diketahui tingkat pemahaman masyarakat lokal sebagai pemangku kepentingan kunci di Tebing Breksi terhadap prinsip-prinsip pariwisata berkelanjutan.

Berdasarkan teori peran pada pemangku kepentingan kunci dari teori Timur \& Getz (2009: 223), teridentifikasi tiga kelompok responden yang terdiri dari Kelompok Pemerintah Desa Sambirejo. Kelompok Komunitas Lokal dan Kelompok Penyedia Jasa Lokal. Hasil penelitian menunjukkan bahwa masyarakat lokal sebagai pemangku kepentingan kunci di Tebing Breksi memiliki tingkat pemahaman yang tinggi terhadap prinsipprinsip pariwisata berkelanjutan dengan nilai ratarata 4,19. Meskipun demikian, tingkat pemahaman masyarakat lokal sebagai pemangku kepentingan kunci tidak dapat digeneralisasikan karena terdapat perbedaan nilai rata-rata di setiap kelompok responden. Tingkat pemahaman pada Kelompok Pemerintah Desa Sambirejo terhadap SUSTDI lebih tinggi dengan nilai rata-rata 4,24 daripada Kelompok Komunitas Lokal yang memiliki nilai rata-rata 4,14 dan Kelompok Penyedia Jasa Lokal dengan nilai rata-rata 4,20 .

Setelah melalui serangkaian analisis yang telah dipaparkan, hasil dari penelitian ini dapat digunakan oleh akademisi maupun perencana pariwisata sebagai acuan dalam mengembangkan program pendidikan dan pelatihan yang tepat, yang berguna untuk meningkatkan pemahaman dan pengetahuan masyarakat lokal sebagai pemangku kepentingan kunci berkaitan dengan bagaimana seharusnya prinsip-prinsip pariwisata berkelanjutan itu dilaksanakan.

\subsection{Rekomendasi}

Berdasarkan hasil pembahasan yang telah dipaparkan, terdapat beberapa saran terkait penelitian selanjutnya. Pertama, penelitian ini dilakukan dengan metode kuantitatif deskriptif sehingga memiliki kelemahan untuk melakukan hubungan sebab akibat dan mengekplorasi hubungan sebab akibat tersebut. Oleh karena itu, perlu adanya penelitian SUSTDI yang dilakukan dengan 
menggunakan metode gabungan antara kuantitatif dan kualitatif sehingga dapat meningkatkan kekuatan hasil penelitian SUSTDI sebagai acuan perencana pariwisata dalam mewujudkan pariwisata berkelanjutan pada destinasi wisata.

Kedua, penelitian ini menemukan indikasi bahwa masyarakat lokal sebagai pemangku kepentingan kunci di Tebing Breksi memiliki peran ganda yang tumpang tindih di dalam struktur organisasi. Hal ini menarik untuk dibahas dalam penelitiaan selanjutnya tentang peran ganda pada masyarakat lokal sebagai pemangku kepentingan kunci di dalam pengelolaan destinasi wisata yang berbasis masyarakat.

Ketiga, penelitian selanjutnya dapat melihat apakah terjadi perubahan seperti peningkatan ataupun penurunan tingkat pemahaman masyarakat lokal sebagai pemangku kepentingan kunci di Tebing Breksi Yogyakarta terhadap prinsip-prinsip pariwisata berkelanjutan setelah diujikannya SUSTDI melalui penelitian ini. Selain itu, penelitian selanjutnya juga dapat dilakukan untuk mengetahui apakah adanya tindak lanjut untuk melakukan program pendidikan dan pelatihan predalam rangka meningkatkan pemahaman dan pengetahuan pemangku kepentingan terhadap prinsip-prinsip pariwisata berkelanjutan.

\section{Catatan Akhir}

1) Aini, N. 2017. "Suka Selfie? Kemenpar akan Kembangkan Wisata Digital", http://www. republika.co.id/berita/ekonomi/makro/17/12/12/ p0udxu382-suka-selfie-kemenpar-akankembangkan-wisata-digital diakses pada Selasa, 30 Januari 2018 pukul. 11:29 WIB.

2) Sulistiarmi, W. 2017. "Definisi Spot Fotogenik bagi Seorang Fotografer dan Wisatawan Lokal", https://phinemo.com/pro-kontra-spot-fotogenikdi-destinasi-wisata-masa-kini-di-indonesial diakses pada Rabu, 16 Mei 2018, pukul. 15:36 WIB.

3) Warganet (KBBI, 2018)

4) Bersifat menyebar luas dan cepat seperti virus (KBBI, 2017)

5) Wawancara Bapak Ngatijo, Kepala Bagian Pembangunan Pemerintah Desa Sambirejo pada 1 Maret 2018, Pukul. 11.00-11.30 WIB

6) geo- yang berarti "bumi" dan heritage- "warisan" adalah situs atau area geologi yang memiliki nilainilai yang penting di bidang keilmuan, pendidikan, budaya dan nilai estetika (The Geological Society of Amerika, 2012)

\section{Daftar Pustaka}

Arsip, sumber resmi tercetak dan sumber Internet

Anonim. 2018. "Kamus Besar Bahasa Indonesia (KBBI) Daring". https://kbbi.kemdikbud.go.id/. Diakses pada Selasa, 30 Januari 2018. Pukul. 14.42 WIB.

Anonim. 2017. "Tebing Breksi Jadi Juara Wisata Baru Terpopuler 2017". https://lifestyle.okezone.com/ read/2017/11/27/406/1821545/tebing-breksijadi-juara-wisata-baru-terpopuler-2017. Diakses pada Kamis, 10 Mei 2018. Pukul. 14:55 WIB.

Aini, N. 2017. "Suka Selfie? Kemenpar akan Kembangkan Wisata Digital". http://www.republika.co.id/ berita/ekonomi/makro/17/12/12/p0udxu382suka-selfie-kemenpar-akan-kembangkan-wisatadigital. Diakses pada Selasa, 30 Januari 2018. Pukul. 11:29 WIB.

Sulistiarmi, W. 2017. "Definisi Spot Fotogenik bagi Seorang Fotografer dan Wisatawan Lokal". https://phinemo.com/pro-kontra-spot-fotogenikdi-destinasi-wisata-masa-kini-di-indonesia/. Diakses pada Rabu, 16 Mei 2018. Pukul. 15:36 WIB.

\section{Buku, Makalah dan Tulisan IImiah}

Badan Pusat Statistik. 2008. "Penggolongan Pendapatan Penduduk". Jakarta: Badan Pusat Statistik.

Bungin, B. 2005. Metodologi Penelitian Kuantitatif: Komunikasi, Ekonomi, dan Kebijakan Publik Serta Ilmu-Ilmu Sosial Lainnya. Jakarta: Kencana Prenada Media Group.

Byrd, E. T., Cárdenas, D. A., \& Greenwood, J. B. 2008. "Factors of Stakeholder Understanding of Tourism: The Case of Eastern North Carolina. Tourism and Hospitality Research, 8(3): 192-204.

Damanik, J., \& Weber, H.F. 2006. Perencanaan Ekowisata Dari Teori ke Aplikasi.Yogyakarta: Penerbit Andi.

Cárdenas, D. A., Byrd, E. T., \& Duffy, L. N. 2015. “An Exploratory Study of Community Awareness of Impacts and Agreement to Sustainable Tourism Development Principles". Tourism and Hospitality Research, 15(4): 254-266.

Fandeli, C. 2002. Pengusahaan Ekowisata dengan Paradigma dalam Pengusahaan Ekowisata. Yogyakarta: Fakultas Kehutanan Universitas Gadjah Mada. 
Mason, P. 2003. Touirsm Impact, Planning and Management. Oxford: Butterworth-Heinemann. Sakellari, M., \& Skanavis, C. 2013. "Environmental Education and Gender: An Emerging Area of Concern for Environmental Education Research". Applied Environmental Education \& Communication, 12(2): 77-87.

Swarbrooke, John. 1999. Sustainable Tourism Management. New York: CABI Publishing.

Timur, S., \& Getz, D. 2009. "Sustainable Tourism Development: How Do Destination Stakeholders Perceive Sustainable Urban Tourism?". Sustainable Development, 17: 220-232.

Umar, H. 1998. Riset Sumber Daya Manusia. Jakarta: Gramedia Pustaka Utama

UNEP dan UNWTO. 2005. Making Tourism More Sustainable A Guide for Policy Makers. Prancis: UNEP.
UNWTO. 2004. Indicators of Sustainable Development for Tourism Destination: A Guidebook. Madrid: World Tourism Organization.

Yusuf, M. 2014. Metodologi Penelitian Kuantitatif, Kualitatif \& Penelitan. Gabungan. Jakarta: Prenadamedia

Waligo, V. M., Clarke, J., \& Hawkins, R. 2013. "Implementing Sustainable Tourism: A Multi-stakeholder Involvement Management Framework". Tourism Management, 36: 342353.

\section{Wawancara}

Wawancara Bapak Ngatijo, Sleman, Daerah Istimewa Yogyakarta, 1 Maret 2018, Pukul. 11.00-11.30 WIB. 